\title{
microRNA-206 in Rat Medial Prefrontal Cortex Regulates BDNF Expression and Alcohol Drinking
}

\author{
Jenica D. Tapocik, Estelle Barbier, ${ }^{\star}$ Meghan Flanigan,${ }^{\star}$ Matthew Solomon, ${ }^{\star}$ Alexandra Pincus, Andrew Pilling, \\ Hui Sun, Jesse R. Schank, Courtney King, and Markus Heilig \\ Laboratory of Clinical and Translational Studies, National Institute on Alcohol Abuse and Alcoholism, National Institutes of Health, Bethesda, Maryland \\ 20892
}

Escalation of voluntary alcohol consumption is a hallmark of alcoholism, but its neural substrates remain unknown. In rats, escalation occurs following prolonged exposure to cycles of alcohol intoxication, and is associated with persistent, wide-ranging changes in gene expression within the medial prefrontal cortex (mPFC). Here, we examined whether induction of microRNA (miR) 206 in $\mathrm{mPFC}$ contributes to escalated alcohol consumption. Following up on a microarray screen, quantitative real-time reverse transcription PCR ( $\mathrm{qPCR}$ ) confirmed that a history of dependence results in persistent $(>3$ weeks) up-regulation of miR-206 expression in the mPFC, but not in the ventral tegmental area, amygdala, or nucleus accumbens. Viral-mediated overexpression of miR-206 in the mPFC of nondependent rats reproduced the escalation of alcohol self-administration seen following a history of dependence and significantly inhibited BDNF expression. Bioinformatic analysis identified three conserved target sites for miR-206 in the 3' -UTR of the rat BDNF transcript. Accordingly, BDNF was downregulated in post-dependent rats on microarray analysis, and this was confirmed by qPCR. In vitro, BDNF expression was repressed by miR-206 but not miR-9 in a 3'-UTR reporter assay, confirming BDNF as a functional target of miR-206. Mutation analysis showed that repression was dependent on the presence of all three miR-206 target sites in the BDNF $3^{\prime}$-UTR. Inhibition of miR-206 expression in differentiated rat cortical primary neurons significantly increased secreted levels of BDNF. In conclusion, recruitment of miR-206 in the mPFC contributes to escalated alcohol consumption following a history of dependence, with BDNF as a possible mediator of its action.

Key words: addiction; alcohol dependence; BDNF; medial prefrontal cortex; microRNA; self-administration

\section{Introduction}

Alcohol dependence $(\mathrm{AD})$ is characterized by compulsive alcoholseeking and consumption that emerge following prolonged exposure to cycles of intoxication and withdrawal. These behaviors potentially result from persistent neuroadaptations in key brain areas, encoded partly by long-lasting gene-expression changes (Mayfield et al., 2008). Recent studies have shown that the medial prefrontal cortex (mPFC) is sensitive to lasting changes in gene expression following AD (Melendez et al., 2012; Tapocik et al., 2012), demonstrating that the $\mathrm{mPFC}$ and its glutamatergic projection to the nucleus accumbens-shell are critically involved in $\mathrm{AD}$-induced escalated alcohol consumption (Meinhardt et al., 2013). However, the mechanisms underlying dysregulation of gene expression in the mPFC following AD remain unknown.

Recently, we and others performed microarrays identifying dysregulated microRNA ( $\mathrm{miR}$ ) expression in the $\mathrm{mPFC}$ of $\mathrm{AD}$

Received Jan. 31, 2014; accepted Feb. 19, 2014.

Author contributions: J.D.T. and M.H. designed research; J.D.T., E.B., M.F., M.S., A. Pincus, A. Pilling, H.S., J.R.S., and C.K. performed research; J.D.T. and M.H. contributed unpublished reagents/analytic tools; J.D.T., E.B., M.F., M.S., A. Pincus, and H.S. analyzed data; J.D.T. and M.H. wrote the paper.

*E.B., M.F., and M.S. contributed equally to this work.

Correspondence should be addressed to Dr. Jenica D. Tapocik, LCTS/NIAAA/NIH, 10 Center Drive, Bethesda, MD 20892. E-mail: tapocikjd@mail.nih.gov

DOI:10.1523/JNEUROSCI.0445-14.2014

Copyright $\odot 2014$ the authors $\quad 0270-6474 / 14 / 344581-08 \$ 15.00 / 0$ rats and in the anterior cingulate cortex, in postmortem brains of alcoholics (Lewohl et al., 2011; Tapocik et al., 2012). Among the differentially expressed miRs, miR-206 was upregulated after AD. miR-206 is of interest because it represses BDNF expression (Miura et al., 2012). BDNF is an important modulator of synaptic plasticity and mediates long-lasting changes in neuronal connectivity via dendritic spine formation. BDNF signaling activation phosphorylates the cAMP-responsive element binding protein (CREB) resulting in upregulation of CREB-target genes, including the immediate-early gene activity-regulated cytoskeletonassociated (Arc) protein (Messaoudi et al., 2002; Ying et al., 2002; Soulé et al., 2006; Pandey et al., 2008). Arc physically modulates dendritic spine density (DSD) and function (Messaoudi et al., 2007; Bramham et al., 2010). Inhibiting miR-206 in vivo increased BDNF expression and subsequently increased DSD and neurogenesis in the mouse hippocampus (Lee et al., 2012).

Substantial evidence supports a role of BDNF in the regulation of reward and addictive-like behaviors. For example, time-dependent increases in cue-induced cocaine craving after protracted abstinence is associated with a time-dependent increase in BDNF protein within the mesolimbic pathway (Grimm et al., 2003). Furthermore, BDNF injections into the ventral tegmental area (VTA) and nucleus accumbens (NAc) produced persistent enhancement of cocaine-seeking ( $\mathrm{Lu}$ et al., 2004). Conversely, BDNF inhibition in the NAc decreased 
cocaine-seeking (Graham et al., 2007). In contrast, exogenous BDNF injections into the $\mathrm{mPFC}$ decreased cocaine selfadministration (Berglind et al., 2009), seeking (Sadri-Vakili et al., 2010), and cue- and priming-induced reinstatement (Berglind et al., 2007). Different behavioral outcomes have been observed with BDNF for alcohol. Endogenous BDNF has been shown to be a negative modulator of alcohol consumption and reward in BDNF KO mice (Hensler et al., 2003) and in the dorsolateral striatum of rats (Jeanblanc et al., 2009). Until now, a role of endogenous BDNF in the mPFC for alcohol-related behaviors has not been established. However, as observed in cocaineseeking (Sadri-Vakili et al., 2010), aberrant BDNF signaling in the $\mathrm{mPFC}$ may contribute to long-lasting structural changes seen in alcoholism (Poo, 2001; Bramham, 2008).

We identified differential and inversely correlated expression of miR-206 and its target BDNF transcript in the mPFC after AD (Tapocik et al., 2012). These findings suggested that miR-206 regulation of $\mathrm{BDNF}$ in the $\mathrm{MPFC}$ may contribute to addictionlike behaviors that emerge following AD. Here, we asked whether miR-206 is causally related to escalation of alcohol consumption, via modulation of BDNF expression within the $\mathrm{mPFC}$.

\section{Materials and Methods}

Subjects. Male Wistar rats (300-500 g at the outset of the experiment) were housed in pairs in a temperature $\left(21^{\circ} \mathrm{C}\right)$ - and humidity-controlled environment with reversed $12 \mathrm{~h}$ day-night cycles. Rats were given ad libitum access to chow and water for the duration of the experiment, except for two-bottle choice. The studies were conducted in accordance with the NIH Guide for Care and Use of Laboratory Animals.

Total RNA isolation. Total RNA from brain punches including the $\mathrm{mPFC}, \mathrm{NAc}, \mathrm{VTA}$, and amygdala (AMG) of post-dependent (PD; $n=8)$ and control (Ctrl; $n=8)$ rats was isolated using the miRVANA total RNA Isolation Kit (isolating total RNA and miR; Invitrogen). Total RNA quantity was measured on a NanoDrop instrument (Thermo Scientific).

Quantitative real-time reverse transcription PCR. Reverse transcription was performed on 2-10 ng or $1 \mu \mathrm{g}$ of total RNA from mPFC tissue lysates for $\mathrm{miR}$ and gene expression, respectively, per the manufacturer's instructions for the TaqMan miR and Gene Expression Assays (Applied Biosystems) as described previously (Tapocik et al., 2012).

Fluorescence in situ hybridization. Coronal sections $(10-15 \mu \mathrm{m})$ that incorporated the mPFC $(+1.7$ bregma to +3.0 bregma) were obtained from PD $(n=8)$ and Ctrl $(n=8)$ rats on a CM3050S cryostat (Leica Microsystems) at $-20^{\circ} \mathrm{C}$. miR-206 expression was detected as previously described (Silahtaroglu et al., 2007) with a miR-206 or miR-100 LNA probe tagged with fluorescein (40 nM concentration, Exiqon A/S) and images obtained on a Leica SP5 confocal microscope at $20 \times$ and $40 \times$ magnification (Leica Microsystems). miR-206 and miR-100 expression was quantified on Bioquant by measuring the average density of expression per cell.

$m i R$ adenoviral overexpression. miR-206 (AAV2.CB7.CI.EGFP-rnomiR-206.WPRE.rBG) and scrambled (AAV2.CB7.CI.eGFP.rBG) adenoviral vectors (AAVs) were purchased and synthesized from University of Pennsylvania Vector Core (Philadelphia, PA). Rats were anesthetized by inhalation of $1-3 \%$ isoflurane in oxygen and positioned in a stereotaxic frame (Harvard Apparatus). A total of two viral injections were delivered to each side $\left(1 \mu \mathrm{l}\right.$ per injection; viral titer ranged from $1.74 \times 10^{12}$ to $4.65 \times 10^{12}$ genome copies per $\mathrm{ml}$ ) for a total of four injections per rat. The virus was directed to the prelimbic and infralimbic regions of the $\mathrm{mPFC}$ according to the following stereotaxic coordinates: anterior-posterior, $+2.0-2.5 \mathrm{~mm}$ from bregma; medial-lateral (ML), $\pm 0.7 \mathrm{~mm}$ from midline; dorsal-ventral, $-3.30 \mathrm{~mm}$ and $-5.50 \mathrm{~mm}$ from bregma. To deliver the virus, a small hole was drilled through the skull at the ML coordinate, and a stainless steel injector (33 gauge, $14 \mathrm{~mm}$ length) was lowered to the most ventral injection site. The viral supernatant injection was delivered at a rate of $0.25 \mu \mathrm{l}$ per min. After the infusion, the injector was left in place for $2 \mathrm{~min}$. The injector was then raised to the next more dorsal injection site, and the injection procedure was repeated, with the

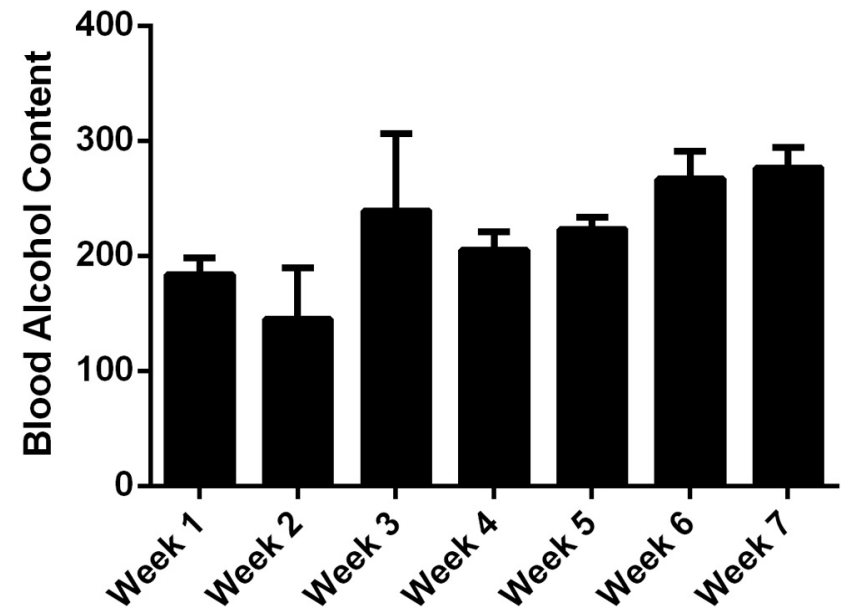

Figure 1. Blood alcohol content (BAC) data for alcohol-dependent rats over the course of 7 weeks. The BAC range averaged $200-300$, a considerably high level of intoxication.

Table 1. Reverse transcription-PCR verification of miR-206 in various brain regions

\begin{tabular}{|c|c|c|c|}
\hline \multirow[b]{2}{*}{ Brain region } & \multicolumn{2}{|c|}{ Fold Change (means \pm SEM) } & \multirow[b]{2}{*}{$p$-value } \\
\hline & Ctrl & PD & \\
\hline $\mathrm{mPFC}$ & $1.01 \pm 0.08$ & $1.45 \pm 0.15^{*}$ & 0.04 \\
\hline Amygdala & $1.02 \pm 0.11$ & $1.40 \pm 0.38$ & 0.38 \\
\hline NAC & $1.01 \pm 0.05$ & $1.02 \pm 0.12$ & 0.94 \\
\hline VTA & $1.04 \pm 0.14$ & $0.920 \pm 0.14$ & 0.55 \\
\hline
\end{tabular}

Data are presented as mean \pm SEM of the $2 \Delta \Delta$ CT value (described in detail in Materials and Methods). ${ }^{*} p<0.05$, significant.

injector left in place for $4 \mathrm{~min}$. The scalp was sutured and the incision site treated with antibiotic ointment.

Alcohol self-administration. Self-administration training and testing were performed as described previously (Schank et al., 2013) using standard operant self-administration chambers (Med Associates). Briefly, chambers consisted of two levers (inactive and active levers), a drinking receptacle, and a cue light. A saccharin fading procedure was used to train animals to self-administer $10 \%(\mathrm{v} / \mathrm{v})$ alcohol in water. Drinking solutions were delivered into a drinking receptacle in a $0.1 \mathrm{ml}$ volume, on a fixed ratio 1 (FR1) reinforcement schedule, during 30 min sessions which were run $5 \mathrm{~d}$ per week. Once $10 \%$ alcohol was self-administered, each alcohol delivery was followed by a $5 \mathrm{~s}$ timeout interval during which responses were recorded but not reinforced. After a stable baseline selfadministration was established, animals were injected with the miR-206 AAV $(n=8)$ or scrambled $(n=8)$ AAV. After a week of recovery, animals were put back on self-administration ( $10 \% \mathrm{v} / \mathrm{v}$ alcohol in water), and the behavior was assessed for $10 \mathrm{~d}$ at a FR1.

Immunohistochemistry. Floating coronal brain sections $(40 \mu \mathrm{M})$ incorporating the $\mathrm{mPFC}(+1.7$ bregma to +3.7 bregma $)$ were obtained from $\mathrm{PD}(n=8)$ and $\operatorname{Ctrl}(n=8)$ rats on a Leica VT 1200 S vibratome. Sections were stored in the $-80^{\circ} \mathrm{C}$ freezer until immunohistochemistry. Floating sections were mounted onto gelatin-coated slides and then washed 3 times with $1 \times$ TBS and then 1 time with $1 \times$ TBS- $0.1 \%$ Tween 20 for 5 min each. The BDNF primary antibody (1:600 dilution, AB6201, AbCam) was added directly to the sections and incubated overnight at $4^{\circ} \mathrm{C}$. The sections were then washed 3 times in $1 \times$ TBS- $0.1 \%$ Tween 20 . The secondary antibody (1:200 dilution, donkey anti-rabbit 555, Life Technologies) was added and incubated at room temperature covered from light. The sections were then washed 1 time with $1 \times$ TBS and left in the dark to dry. They were finally coverslipped using Fluorogel (Dow Corning). The sections were imaged and analyzed on the Leica SP5 confocal microscope at $10 \times$ and $63 \times$.

Alcohol vapor exposure. Wistar rats ( $n=8$ per group and treatment) were exposed to either alcohol vapor (PD) or normal air (Ctrl) using a rodent alcohol inhalation system as described previously (Rimondini et al., 2002). Briefly, the animals were exposed to alcohol for $14 \mathrm{~h}$ 


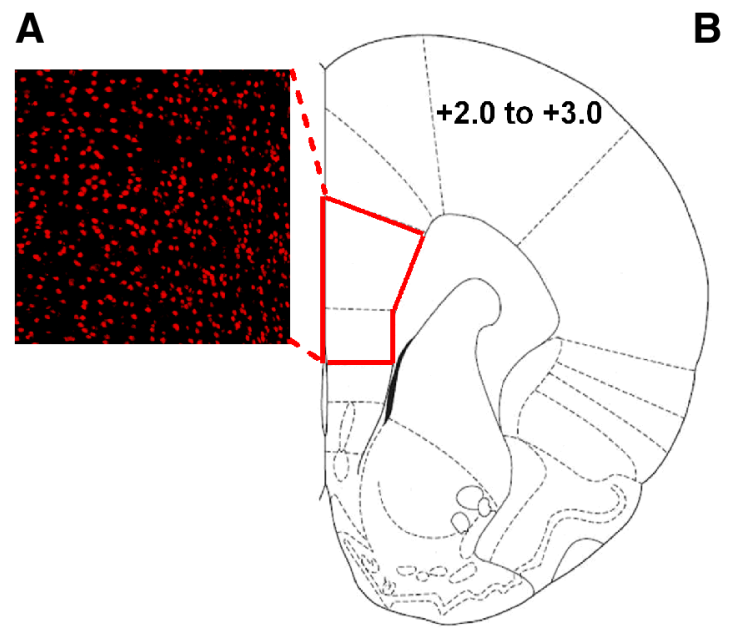

B

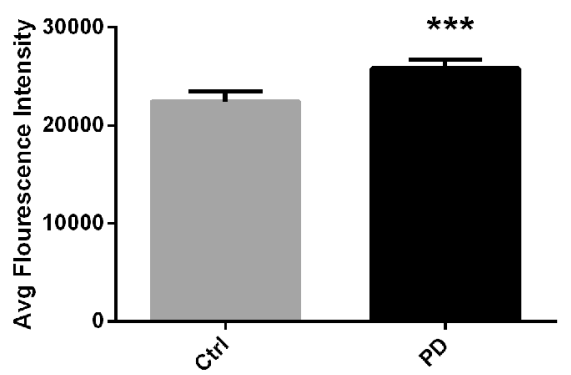

Figure 2. Increased cortical miR-206 expression after 3 weeks' protracted withdrawal in alcohol vapor-exposed rats. A, Left, Representative miR-206 FISH image within the mPFC (10X magnification). Right, The area in which miR-206 in situ hybridization was measured (+2.0 to +3.0 bregma, including both the infralimbic and prelimbic regions of the $\mathrm{mPFC}$. $\boldsymbol{B}$, In situ hybridization identified that miR-206 levels were increased in the mPFC after alcohol vapor 3 weeks after protracted abstinence ${ }^{* * *} p<0.01$, compared with control, $n=8$ per group).

per day (7:30 P.M.-9:30 A.M.) with a $10 \mathrm{~h}$ alcohol off period (9:30 A.M.-7:30 P.M.). The animals were exposed for 7 weeks. As previously published (Sommer et al., 2008; Tapocik et al., 2012), the treatment resulted in blood alcohol concentrations that cycled daily between 0 and $200-380 \mathrm{mg} / \mathrm{dl}$ (Fig. 1). Near the end of the alcohol off cycle, signs of withdrawal in the form of tail stiffness and piloerection were visible.

Nanostring. Total RNA (100 ng) was assayed from mPFC tissue lysates of PD and Ctrl animals on a custom Neurobiology of Addiction NanoString panel (NanoString Technologies) and performed as previously described (Geiss et al., 2008).

Luciferase assays. HEK293 cells were grown on poly-D-lysine in a 96well format to a 70-85\% confluence and transfected using Lipofectamine with $200 \mathrm{ng}$ of psiCHECK-2-BDNF-3'-UTR plasmid (with or without mutations) and 5 pmol of pEGFP-miR-206, pEGFP-mir-9, or scrambled pEGFP mimics (Exiqon). Mutations were introduced at each potential binding site for miR-206 by using the QuikChange II SiteDirected Mutagenesis Kit (Agilent). At 48 h post-transfection, cells were lysed and luciferase reporter activity was assayed using the DualLuciferase Reporter Assay System (Promega). The activities of firefly and Renilla luciferases were measured sequentially from a single sample in a FLUORstar-BMG luminometer (IMGEN) for $60 \mathrm{~s}$ each, immediately after addition of Luciferase Assay Reagent II for firefly luciferase or Stop \& Glo Reagent for Renilla luciferase. Renilla luciferase values were normalized to control firefly luciferase levels (transcribed from the same vector but not affected by the $3^{\prime}$-UTR tested) and averaged across 3-5 well repetitions.

Primary neuronal cultures. Primary rat cortical neurons were obtained from Neuromics and plated according to the company's instructions. Neurons were plated in 6-well plates coated with poly-D-lysine at $\sim 300,000$ cells/well for all treatment groups. Cells were maintained in NbActiv4 medium and half of the medium was changed every 3-4 d throughout the experiment, except directly following lentivirus infection.

In vitro lentivirus infection. After $10 \mathrm{~d}$ in culture, rat primary cortical neurons were infected at a ratio of 30 infection units/cell with either a miR-206 knockdown or scrambled lentivirus (Genecopoeia). The lentiviruses contained an $\mathrm{H} 1$ promoter for expression of the miR knockdown or scrambled control cassette and a CMV promoter for expression of the fluorescent reporter mCherry. Cell medium was fully replaced $48 \mathrm{~h}$ after infection.

$B D N F$ assay. Primary neuron culture medium was collected at 3, 8, and $12 \mathrm{~d}$ following infection with either a miR-206 knockdown or scrambled lentivirus. Secreted BDNF was measured using the Milliplex Rat Pituitary Magnetic Bead Panel (Millipore) according to the manufacturer's instructions.
Statistics. All data were analyzed by either a $t$ test or a one- or two-way repeated-measures ANOVA. Significant main or interaction effects were followed by Newman-Keuls post hoc tests where appropriate. All statistical analyses were performed using Statistica software. The level of significance was set at $p \leq 0.05$.

\section{Results}

miR-206 is selectively overexpressed in the mPFC following a history of dependence

miR-206 upregulation in the mPFC was persistent, and was detected 3 weeks after completion of the alcohol exposure $\left(F_{(1,16)}=\right.$ $8.8 ; p=0.005$, fold change $(\mathrm{FC})=1.68$; one-way ANOVA), a time point well beyond acute withdrawal (Tapocik et al., 2012). The upregulation of miR-206 in the mPFC was also regionally selective, and was absent in the VTA, NAc, or AMG (Table 1). Directed by these data, we performed in situ hybridization for miR-206 expression specifically within the mPFC, and confirmed once again an upregulation of $\mathrm{miR}-206$ throughout this region in $\mathrm{PD}$ rats compared with Ctrl rats (Fig. $2, F_{(1,16)}=2.6, p<0.01$, one-way ANOVA). In contrast, the expression of a microRNA not affected by a history of dependence in our previous microarray screen (Tapocik et al., 2012), miR-100, did not differ between groups on in situ hybridization (average density values, Ctrl = $75.6, \mathrm{PD}=87.1 ; p=0.17$ ).

\section{miR-206 overexpression in $\mathrm{mPFC}$ induces escalated} alcohol self-administration

To determine whether upregulated miR-206 is causally related to increased alcohol preference and consumption, we overexpressed it in the mPFC of rats without a history of alcohol dependence (Fig. $3 A, C$ ). miR-206 overexpression was sufficient to induce escalation of alcohol self-administration, measured as alcohol rewards earned per session (Fig. $3 B, F_{(1,16)}=26.9, p<$ 0.0001 , compared with scrambled Ctrl vector, one-way ANOVA). miR-206 overexpression accounted for $49 \%$ of the variance in self-administration (partial $\eta$-square). A similar effect of miR-206 expression was also seen on the number of operant responses emitted (miR206 AAV lever presses $(\mathrm{LP})=49 \pm$ 1.7; scrambled AAV LP $=41 \pm 2.0, F_{(1,16)}=7.2, p=0.012$, compared with scrambled Ctrl, one-way ANOVA). Immunohistochemistry confirmed that miR-206 overexpression (Fig. 3C,D) led to a significant reduction in BDNF protein expression $(t(9)=$ $2.57 ; p=0.03$; Fig. 3D-F). 
miR-206 inhibits BDNF expression

miR-206 putatively targets BDNF (Horch et al., 1999). Accordingly, we found BDNF expression (BDNF exon IV) significantly downregulated in the MPFC of PD rats by quantitative real-time reverse transcription PCR (qPCR) (Fig. 4A) and independently confirmed this finding by NanoString (FC $=-1.56, p=0.03$, oneway ANOVA). Downregulated BDNF expression was accompanied by upregulated expression of the high-affinity receptor for BDNF, neurotrophic tyrosine kinase receptor type 2 (Ntrk2 or TrkB; Fig. $4 B$ for qPCR; Nanostring: $\mathrm{FC}=1.13, p=0.006$, one-way ANOVA). BDNF transcript was not changed in the VTA or AMG, but was upregulated in the NAc (Fig. 5, BDNF: FC +1.38 , BDNF exon IV: FC +1.27).

The rat BDNF 3'-UTR is 2868 bases. Bioinformatic analysis using microRNA. org identified 3 conserved rno-miR-206 target sites in the BDNF 3 '-UTR, at positions 214, 392, and 1294 (site 1, 2, 3, respectively). Each site within the $3^{\prime}$-UTR is complementary to the seed sequence of the miR-206 family of miRNAs (Fig. 4C). In a dual luciferase reporter assay, BDNF expression was repressed by miR-206 by $60 \%(p<0.05$, one-way ANOVA) but not miR-9 or a scrambled control (Fig. $4 D)$. Furthermore, site-directed mutagenesis of site 1,2, or 3 alone did not diminish BDNF repression (Fig. $4 E, p<$ 0.05 , one-way ANOVA). However, attenuation of BDNF repression was dependent on the presence of sites 2 and 3 .

\section{miR-206 regulates BDNF expression and secretion in rat cortical primary neurons}

To determine whether miR-206 regulation of BDNF transcript levels has functional consequences for BDNF release, we measured secreted BDNF protein after miR-206 manipulation in cultures of differentiated rat cortical primary neurons. In this in vitro assay, inhibition of miR206 resulted in increased levels of secreted BDNF protein compared with controls (Fig. 6; main effect of treatment $\left.F_{(1,9)}=5.67, p=0.04\right)$. Levels of secreted BDNF also changed over time (main effect of day $F_{(2,18)}=13.03, p=$ 0.0003 ), but the effect of miR-206 was approximately equal in magnitude through the duration of the experiment (no treatment $\times$ day interaction $\left.F_{(2,18)}=0.8221, p=0.45\right)$. Thus, miR206 regulation of BDNF transcript levels results in altered BDNF protein secretion from rat cortical neurons, a prerequisite for functional consequences on downstream processes.

\section{Discussion}

We report here that a history of alcohol dependence results in a regionally selective induction of miR-206 expression in the mPFC, accompanied by decreased BDNF expression in this re-

B

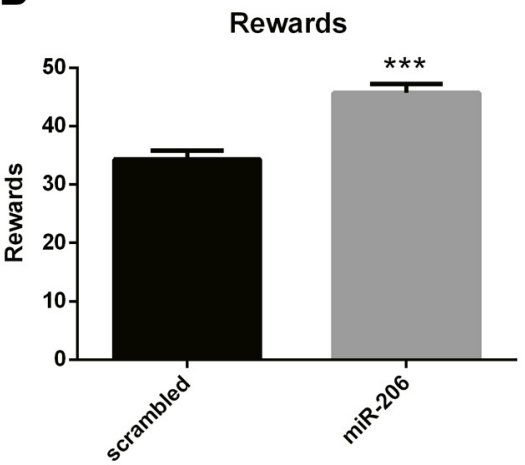

D

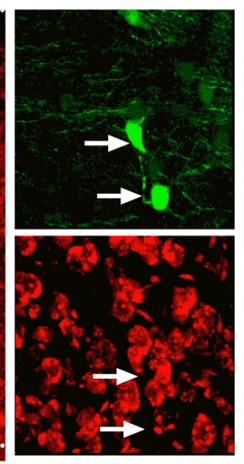

E
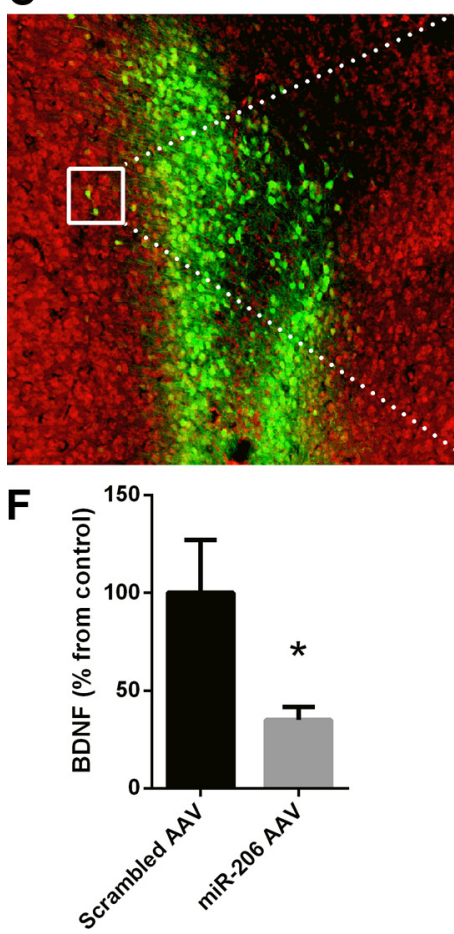

Figure 3. Effects of cortical miR-206 overexpression on alcohol self-administration. $A$, Representative mapping of viral injection sites within the $\mathrm{mPFC}$ denoted by an $\mathrm{X}$ (between +2.2 and +3.7 bregma). $\boldsymbol{B}$, miR-206 overexpression significantly increased rewards during operant self-administration. The self-administration data represent the average of the last $10 \mathrm{~d}$ of selfmiR-206 overexpression virus (tagged with GFP, in green) and colabeled with BDNF (in red) at $10 \times$ magnification. $\boldsymbol{D}$, A zoomed-in picture of the white panel in C $(63 \times$ magnification) of the miR-206 overexpression AAV-infected cells (top, green; white arrows denote two infected cells) and BDNF expression (bottom, red; white arrows denote reduced BDNF expression). $\boldsymbol{E}$, Colocalization of miR-206 overexpression AAV-infected cells and BDNF. $F$, Quantification of BDNF in infected cells, presented as percentage of the average density of BDNF expression per infected cell compared with scrambled, ${ }^{*} p=0.028$. gion. We also show that miR-206 binds to and inhibits the expression of the BDNF transcript (in vitro) and protein (in vivo), as well as the secretion of BDNF protein in cortical neurons in vitro. Most importantly, our findings establish a causal relationship between miR-206 expression and alcohol-related behaviors, since overexpression of miR-206 in nondependent rats inhibited BDNF expression in vivo, and reproduced escalation of alcohol self-administration. This regulation strongly supports the notion that changes in miR-206 expression causally contribute to modulation of alcohol self-administration by the MPFC and identify $\mathrm{BDNF}$ as a candidate mediator of this mechanism.

Increased alcohol self-administration following a history of dependence is associated with disrupted behavioral control, evidenced, for example, by aversion-insensitive consumption (Ven- 
A

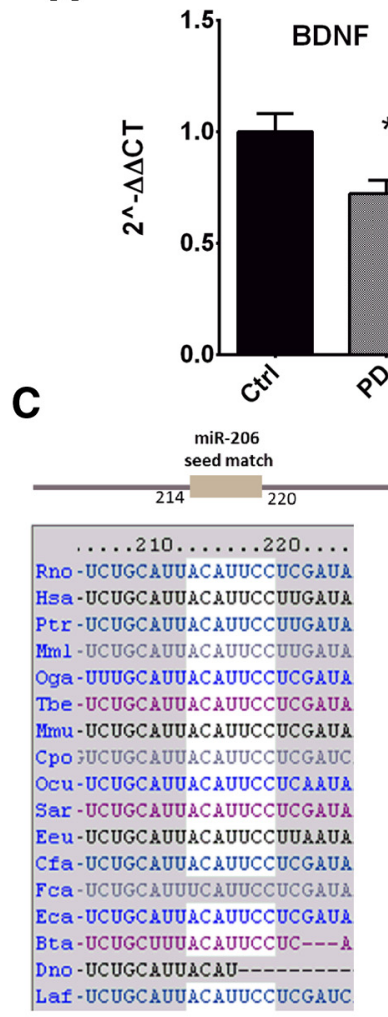

D

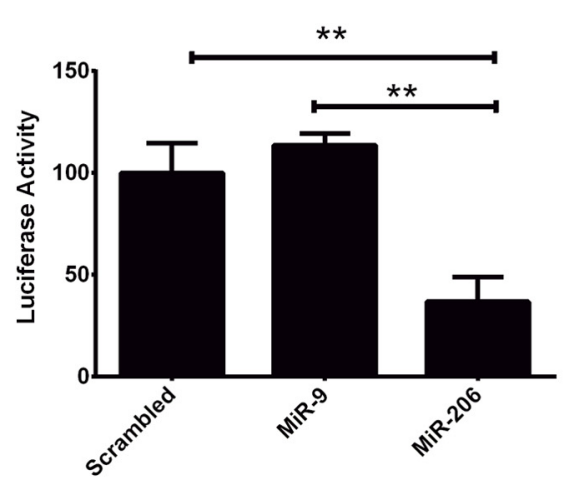

B

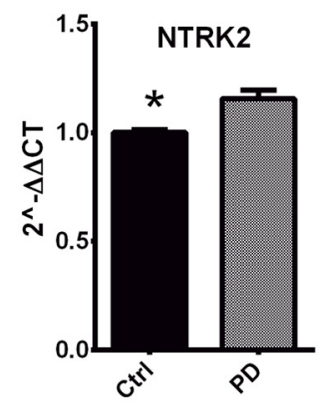

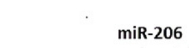
$292 \quad-\frac{398}{392}$ $\ldots 390 \ldots .400 \ldots$ Rno . CCAAAACAUUCCGUUUAC? Hsa .CCAAAACAUUCCGUUUAC? Ptr . CCAAAACAUUCCGUUUAC2 Mml cCAAAAACAUUCCGUUUAC Oga .CCCAAACAUUCCGUUUAC Tbe .CCAAAACAUUCCGUUUCC? Mmu .CCAAAACAUUCCGUUUAC? COO CCAAAACAUUCCGUUUAC Ocu .CCAAAACAUUCCGUUUAC Sar .CCAAAACAUUCCGUUUAC? EeU .CCAAAACAUUCCGUUUACI Cfa .CCAAAACAUUCCGUUUAC Fca CCAAAACAUUCCGUUUAC Eca CCAAAACAUUCCGUUUAC? Bta . CCAAAACAUUCCGUUUAC? Dno Laf .CCAAAACAUCCCGUUUAC?

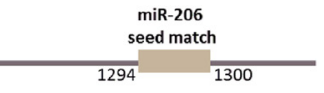

$1290 \ldots \ldots 1300 \ldots . . .$. Rno-CUUG AG AC BUUCCU- \&AAG Hsa-UUUGAGACAUUCCA-AAACG. PEr -UUUGAGACAUUCCA-AAACG. Oga -CUUG-GACAUUCCA-AAAAA The -CUUGAGACAUUCCA-CAAGG. Mru - CUUGAGACAUUCCU-AARG CDO-CUCGAGAUGCUCCU- $\triangle \mathrm{CAGG}$ OCU -UUUG AGACAUUCCA-AAAGG Sar -CUUGAGACAUUCCA-AAAGG

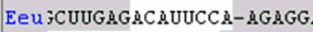
Cfa-C------DUUCCG-GARGG FCa-CUUGAGACAUUCCAMGUAGG ECa-CUUGAGACAUUCCA-AARGG Bta-CUUGAGACAUUCCA-GARGG Dno

Laf -CUUGRGACAUUCCA-A.AGGG

\section{E}

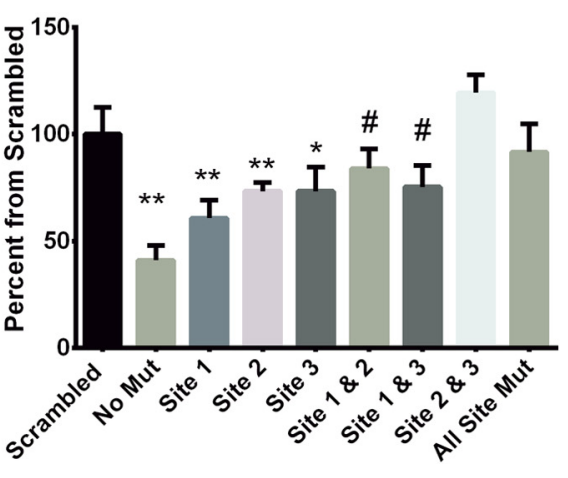

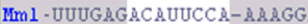

Figure 4. miR-206 regulates the expression of BDNF via three seed matches on its $3^{\prime}$-UTR. $A, B$, Nanostring verification of BDNF $(\boldsymbol{A})$ and its receptor, NTRK2, expression (B). C, Target scan identified 3 putative binding targets of miR-206 on the $3^{\prime}$-UTR of BDNF. D, Luciferase activity measured in HEK293T cells cotransfected with either miR-206 mimic, miR-9 mimic, or scrambled mimic, and a luciferase reporter plasmid carrying the $3^{\prime}$-UTR of BDNF. Renilla luciferase activity was normalized by firefly luciferase expression levels and is presented as percentage of activity achieved by the 3' -UTR of BDNF in the presence of either mimic (miR-206, miR-9, scrambled). $\boldsymbol{E}$, Luciferase activity measured in HEK293T cells with miR-206 or scrambled mimic and a luciferase reporter plasmid with mutations at site 1 (214-220), site 2 (392-398), site $3(1294-1300)$, combinations with these sites, or all sites mutated. ${ }^{* *} p<0.01,{ }^{*} p<0.05,{ }^{\#} p=0.05-0.1$ (trend significance).

druscolo et al., 2012). Our present findings suggest that the emergence of these behaviors may result from alcohol-induced impairments of synaptic plasticity that are downstream of miR206 induction. The data are consistent with the hypothesis that increased expression of miR-206 caused by chronic brain alcohol exposure and the resulting decrease in BDNF expression within the $\mathrm{mPFC}$ lead to impaired synaptic plasticity in the $\mathrm{mPFC}$ or its targets, regions that regulate alcohol intake.

miR-206 is largely known as a skeletal muscle-specific miR that is required for efficient regeneration at the neuromuscular junction after acute nerve injury (Williams et al., 2009). In the normal human or rodent brain, miR-206 is expressed at very low basal levels, but its expression is induced under disease conditions, such as in Alzheimer's disease. For instance, high expression of miR-206 was shown in brains of Alzheimer's disease transgenic mice and in the temporal cortex of Alzheimer's disease patients (Lee et al., 2012). Our findings indicate that brain alcohol exposure is an insult that also results in a persistent, region-specific induction of miR-206 expression, with clear consequences for neuronal function and behavior. This is, to our knowledge, the first report of regionally induced miR206 expression in the rat brain resulting from alcohol dependence. Our experiments point to a mechanistic role for miR-206 in behaviors that emerge following a history of dependence.

Our finding that miR-206 is able to directly repress BDNF translation is in agreement with previous studies and supports the notion that miR-mediated changes in synaptic plasticity may underlie behavioral consequences of alcohol dependence (Lee et al., 2012; Miura et al., 2012). BDNF is a potent modulator of synaptic transmission and plasticity in cortical neurons (Horch et al., 1999) and is involved in the regulation of alcohol consumption and preference in nondependent animals (McGough et al., 2004). $\mathrm{BDNF}$ is also involved in the regulation of structural as well as functional synaptic plasticity, which is altered by exposure to drugs of abuse (Sadri-Vakili et al., 2010). Notably, we demonstrated that cortical miR-206 overexpression decreased endogenous BDNF protein levels within infected cells, and this was associated with increased alcohol self-administration. Both human and animal studies suggest that impairment of mPFC function is a key factor behind escalated alcohol drinking (Tu et al., 2007; Beck et al., 2012), while BDNF has been shown to regulate various aspects of drug-taking behavior. For instance, shRNA-induced BDNF various aspects of drug-taking behavior knockdown in the mPFC increased the breakpoint in a cocaine progressive ratio self-administration paradigm (Sadri-Vakili et al., 2010), while BDNF infused into the mPFC attenuated cocaine-seeking (Berglind et al., 2007). In contrast, BDNF injections directly into the NAc increased cocaine self-administration, progressive ratio, extinction, and reinstatement, and these effects were reversed when BDNF was inhibited (Graham et al., 2007). Interestingly, we observed an upregulation of BDNF in the NAc after alcohol dependence. This is opposite to what is seen with alcohol within the dorsolateral striatum (Jeanblanc et al., 2009).

Our results establish that miR-206 can inhibit cortical BDNF in vivo as well as regulate BDNF secretion from cortical neurons, 
suggesting that miR-206 has the ability to control the expression of a subset of critical target proteins that lead to an escalation in alcohol self-administration behaviors. Changes in BDNF expression can disrupt synaptic strength in the connections from the mPFC to NAc and AMG, which can alter alcohol consumption (George et al., 2012). Furthermore, our present findings suggest that effects of BDNF on synaptic plasticity (Kang and Schuman, 1995) and its role as a synaptic modulator (Poo, 2001) may be required for the mPFC to maintain control over alcohol consumption. BDNF signaling has been shown to counteract neuroadaptations that contribute to the development or maintenance of the reinforcing effects of drugs of abuse through effects in the mPFC (Sadri-Vakili et al., 2010) and the dendritic spine through homeostatic interactions with miR-212 and the transcriptional repressor methyl CpG binding protein 2 (Im et al., 2010).

Two of the main downstream target proteins of BDNF are its receptor, TrkB, and Arc, a cytoskeleton-associated protein. BDNF and TrkB receptors are found in postsynaptic densities (PSDs) at excitatory glutamatergic synapses in the cortex (Aoki et al., 2000). The PSD localization of both BDNF and TrkB supports the notion that this receptor/ligand pair participates in postsynaptic plasticity. In agreement, we found an inverse correlation of BDNF and TrkB receptor expression in our post-dependent rats. The inverse correlation between receptor and ligand reflect a homeostatic mechanism that attempts to restore BDNF signaling after alcohol exposure. Because the TrkB receptor expression changes were low (fold change $<1.2$ ), they may be insufficient to compensate for the impaired BDNF expression and signaling.

Consistent with the miR-206-mediated BDNF repression, we have previously found that Arc was downregulated in rats with a history of alcohol dependence (Tapocik et al., 2012). Arc is an inducible early gene involved in drug-related behaviors. For example, Arc expression is altered in the mPFC during a single session of cocaine self-administration (Fumagalli et al., 2009) and relapse to heroin seeking (Fanous et al., 2013). More importantly, Arc plays a prominent role in mediating the effects of acute as well as long-term alcohol exposure (Pandey et al., 2008). It may be relevant for synaptic plasticity that occurs in alcohol dependence, because it is localized to the dendrites and is quickly activated by synaptic stimulation (Rodríguez et al., 2005). Furthermore, activation of BDNF has been shown to stimulate one or more of the three major signaling pathways involving mitogen-activated protein kinase (MAPK), phosphatidylinositol-3-kinase (PI3K), and phospholipase-Cg (PLC-g), which may be involved in specific behavioral outcomes of drugs of abuse (Nagappan and Lu, 2005). Against that background, it is interesting to note that genes involved in MAPK signaling (Dusp1, Dusp6) were downregulated
NAC BDNF

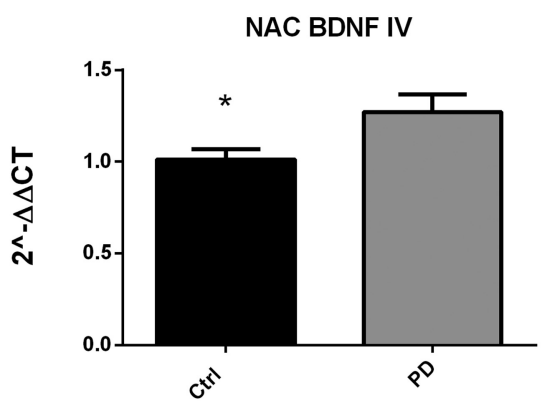

AMG BDNF IV

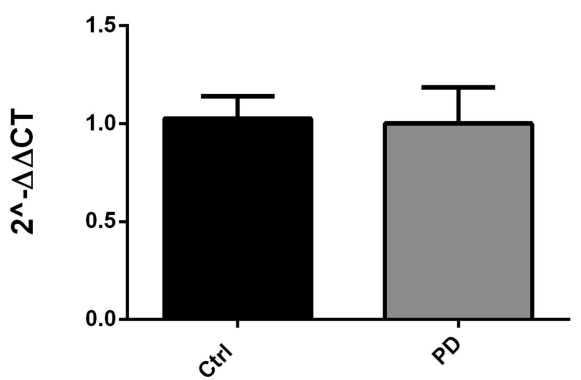

VTA BDNF IV

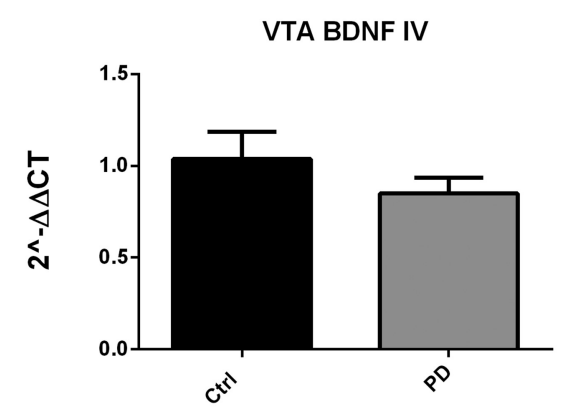
VTA BDNF

Figure 5. $P C R$ validation of BDNF and BDNF isoform IV in the NAC, AMG, and VTA. BDNF and BNDF IV were significantly

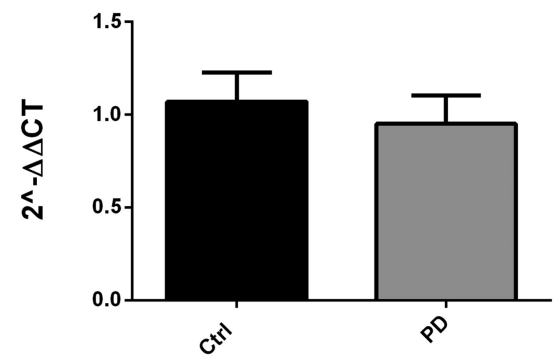

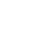


A

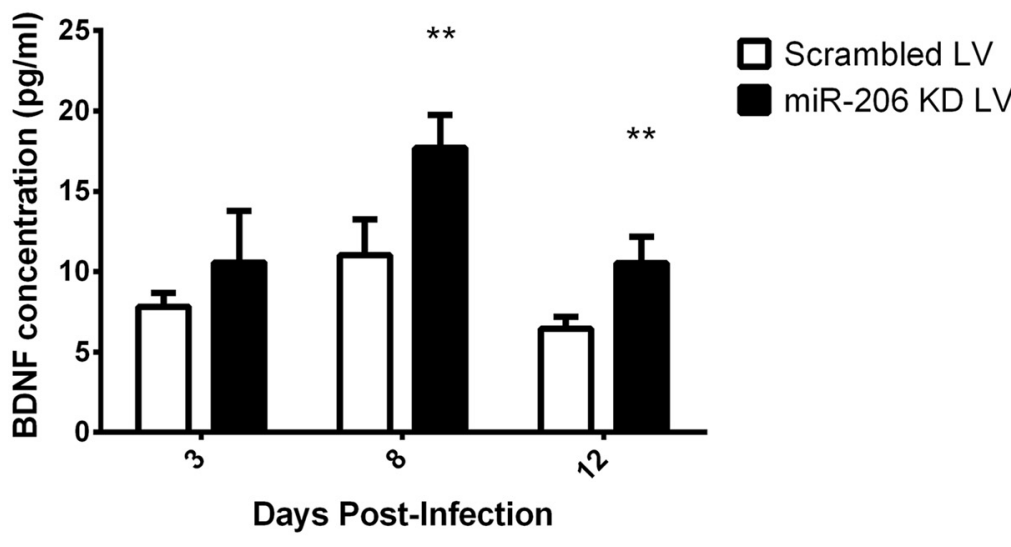

B

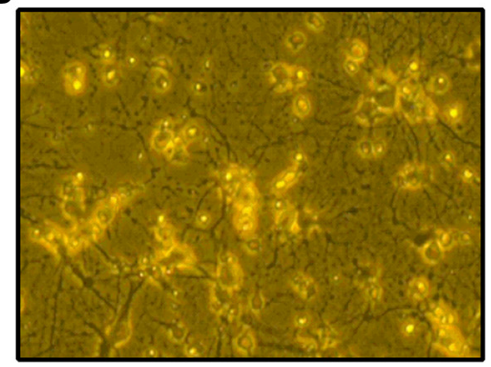

C

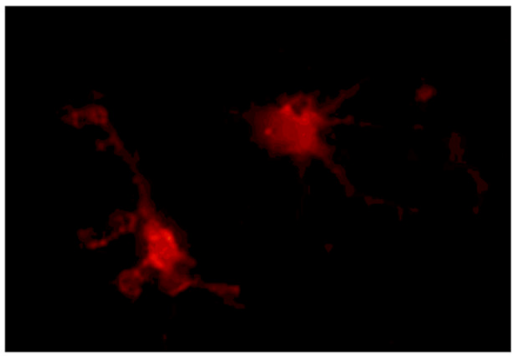

Figure 6. miR-206 inhibition increases secreted BDNF in primary cortical rat neurons. $A$, miR-206 knockdown lentivirus (KD LV) significantly increased secreted BDNF in rat primary cortical neuron cultures with respect to scrambled lentivirus-infected controls. There was a main effect of treatment, $F_{(1,9)}=5.67, p=0.041$, and a main effect of day, $F_{(2,18)}=13.03 p=0.0003$, but no treatment vs day interaction, $F_{(2,18)}=0.8221, p=0.45$. B, Representative bright-field images of rat primary cortical neurons after 3 weeks in culture at $20 \times$ magnification. C, Sample of two neurons that were infected with the miR-206 KD LV containing an $\mathrm{mCherry} \mathrm{reporter} 2$ weeks postinfection and 3 weeks in culture at $40 \times$ zoom magnification.

gether, these findings suggest that a long-lasting induction of miR-206 expression and its regulation of BDNF after prolonged brain exposure to alcohol may alter the function of neural circuits involved in the cognitive control of alcohol consumption, ultimately contributing to alcohol dependence.

\section{References}

Aoki C, Wu K, Elste A, Len Gw, Lin Sy, McAuliffe G, Black IB (2000) Localization of brain-derived neurotrophic factor and TrkB receptors to postsynaptic densities of adult rat cerebral cortex. J Neurosci Res 59:454-463. CrossRef Medline

Beck A, Wüstenberg T, Genauck A, Wrase J, Schlagenhauf F, Smolka MN, Mann K, Heinz A (2012) Effect of brain structure, brain function, and brain connectivity on relapse in alcohol-dependent patients. Arch Gen Psychiatry 69:842-852. CrossRef Medline

Berglind WJ, See RE, Fuchs RA, Ghee SM, Whitfield TW Jr, Miller SW, McGinty JF (2007) A BDNF infusion into the medial prefrontal cortex suppresses cocaine seeking in rats. Eur J Neurosci 26:757-766. CrossRef Medline

Berglind WJ, Whitfield TW Jr, LaLumiere RT, Kalivas PW, McGinty JF (2009) A single intra-PFC infusion of BDNF prevents cocaine-induced alterations in extracellular glutamate within the nucleus accumbens. J Neurosci 29:3715-3719. CrossRef Medline

Bramham CR (2008) Local protein synthesis, actin dynamics, and LTP consolidation. Curr Opin Neurobiol 18:524-531. CrossRef Medline

Bramham CR, Alme MN, Bittins M, Kuipers SD, Nair RR, Pai B, Panja D, Schubert M, Soule J, Tiron A, Wibrand K (2010) The Arc of synaptic memory. Exp Brain Res 200:125-140. CrossRef Medline

Crews FT, Zou J, Qin L (2011) Induction of innate immune genes in brain create the neurobiology of addiction. Brain Behav Immun 25 [Suppl 1]: S4-S12.

Fanous S, Guez-Barber DH, Goldart EM, Schrama R, Theberge FR, Shaham Y, Hope BT (2013) Unique gene alterations are induced in FACS- purified Fos-positive neurons activated during cue-induced relapse to heroin seeking. J Neurochem 124:100-108. CrossRef Medline Fumagalli F, Franchi C, Caffino L, Racagni G, Riva MA, Cervo L (2009) Single session of cocaine intravenous self-administration shapes goal-oriented behaviours and upregulates Arc mRNA levels in rat medial prefrontal cortex. Int J Neuropsychopharmacol 12:423-429. CrossRef Medline

Geiss GK, Bumgarner RE, Birditt B, Dahl T, Dowidar N, Dunaway DL, Fell HP, Ferree S, George RD, Grogan T, James JJ, Maysuria M, Mitton JD, Oliveri P, Osborn JL, Peng T, Ratcliffe AL, Webster PJ, Davidson EH, Hood L, Dimitrov K (2008) Direct multiplexed measurement of gene expression with color-coded probe pairs. Nat Biotechnol 26:317-325. CrossRef Medline

George O, Sanders C, Freiling J, Grigoryan E, Vu $\mathrm{S}$, Allen CD, Crawford E, Mandyam CD, Koob GF (2012) Recruitment of medial prefrontal cortex neurons during alcohol withdrawal predicts cognitive impairment and excessive alcohol drinking. Proc Natl Acad Sci U S A 109:18156-18161. CrossRef Medline

Graham DL, Edwards S, Bachtell RK, DiLeone RJ, Rios M, Self DW (2007) Dynamic BDNF activity in nucleus accumbens with cocaine use increases self-administration and relapse. Nat Neurosci 10:1029-1037. CrossRef Medline

Greco SJ, Rameshwar P (2007) MicroRNAs regulate synthesis of the neurotransmitter substance $\mathrm{P}$ in human mesenchymal stem cellderived neuronal cells. Proc Natl Acad Sci U S A 104:15484-15489. CrossRef Medline

Grimm JW, Lu L, Hayashi T, Hope BT, Su TP, Shaham Y (2003) Time-dependent increases in brain-derived neurotrophic factor protein levels within the mesolimbic dopamine system after withdrawal from cocaine: implications for incubation of cocaine craving. J Neurosci 23: 742-747. Medline

Haas JD, Nistala K, Petermann F, Saran N, Chennupati V, Schmitz S, Korn T, Wedderburn LR, Förster R, Krueger A, Prinz I (2011) Expression of miRNAs miR-133b and miR-206 in the Il17a/f locus is co-regulated with IL-17 production in alphabeta and gammadelta T cells. PloS One 6:e20171. CrossRef Medline

Hensler JG, Ladenheim EE, Lyons WE (2003) Ethanol consumption and serotonin-1A (5-HT1A) receptor function in heterozygous BDNF $(+/-)$ mice. J Neurochem 85:1139-1147. CrossRef Medline

Horch HW, Krüttgen A, Portbury SD, Katz LC (1999) Destabilization of cortical dendrites and spines by BDNF. Neuron 23:353-364. CrossRef Medline

Im HI, Hollander JA, Bali P, Kenny PJ (2010) MeCP2 controls BDNF expression and cocaine intake through homeostatic interactions with microRNA-212. Nat Neurosci 13:1120-1127. CrossRef Medline

Jeanblanc J, He DY, Carnicella S, Kharazia V, Janak PH, Ron D (2009) Endogenous BDNF in the dorsolateral striatum gates alcohol drinking. J Neurosci 29:13494-13502. CrossRef Medline

Kang HJ, Schuman EM (1995) Neurotrophin-induced modulation of synaptic transmission in the adult hippocampus. J Physiol Paris 89:11-22. CrossRef Medline

Lee ST, Chu K, Jung KH, Kim JH, Huh JY, Yoon H, Park DK, Lim JY, Kim JM, Jeon D, Ryu H, Lee SK, Kim M, Roh JK (2012) miR-206 regulates brainderived neurotrophic factor in Alzheimer disease model. Ann Neurol 72:269-277. CrossRef Medline

Lewohl JM, Nunez YO, Dodd PR, Tiwari GR, Harris RA, Mayfield RD (2011) Up-regulation of microRNAs in brain of human alcoholics. Alcohol Clin Exp Res 35:1928-1937. CrossRef Medline

Lu L, Dempsey J, Liu SY, Bossert JM, Shaham Y (2004) A single infusion of brain-derived neurotrophic factor into the ventral tegmental area induces 
long-lasting potentiation of cocaine seeking after withdrawal. J Neurosci 24:1604-1611. CrossRef Medline

Mayfield RD, Harris RA, Schuckit MA (2008) Genetic factors influencing alcohol dependence. Br J Pharmacol 154:275-287. Medline

McGough NN, He DY, Logrip ML, Jeanblanc J, Phamluong K, Luong K, Kharazia V, Janak PH, Ron D (2004) RACK1 and brain-derived neurotrophic factor: a homeostatic pathway that regulates alcohol addiction. J Neurosci 24:10542-10552. CrossRef Medline

Meinhardt MW, Hansson AC, Perreau-Lenz S, Bauder-Wenz C, Stählin O, Heilig M, Harper C, Drescher KU, Spanagel R, Sommer WH (2013) Rescue of infralimbic mGluR2 deficit restores control over drug-seeking behavior in alcohol dependence. J Neurosci 33:2794-2806. CrossRef Medline

Melendez RI, McGinty JF, Kalivas PW, Becker HC (2012) Brain regionspecific gene expression changes after chronic intermittent ethanol exposure and early withdrawal in C57BL/6J mice. Addict Biol 17:351-364. CrossRef Medline

Messaoudi E, Ying SW, Kanhema T, Croll SD, Bramham CR (2002) Brainderived neurotrophic factor triggers transcription-dependent, late phase long-term potentiation in vivo. J Neurosci 22:7453-7461. Medline

Messaoudi E, Kanhema T, Soulé J, Tiron A, Dagyte G, da Silva B, Bramham CR (2007) Sustained Arc/Arg3.1 synthesis controls long-term potentiation consolidation through regulation of local actin polymerization in the dentate gyrus in vivo. J Neurosci 27:10445-10455. CrossRef Medline

Miura P, Amirouche A, Clow C, Bélanger G, Jasmin BJ (2012) Brainderived neurotrophic factor expression is repressed during myogenic differentiation by miR-206. J Neurochem 120:230-238. CrossRef Medline

Nagappan G, Lu B (2005) Activity-dependent modulation of the BDNF receptor TrkB: mechanisms and implications. Trends Neurosci 28:464471. CrossRef Medline

Pandey SC, Zhang H, Ugale R, Prakash A, Xu T, Misra K (2008) Effector immediate-early gene arc in the amygdala plays a critical role in alcoholism. J Neurosci 28:2589-2600. CrossRef Medline

Poo MM (2001) Neurotrophins as synaptic modulators. Nat Rev Neurosci 2:24-32. CrossRef Medline

Rimondini R, Arlinde C, Sommer W, Heilig M (2002) Long-lasting increase in voluntary ethanol consumption and transcriptional regulation in the rat brain after intermittent exposure to alcohol. FASEB J 16:27-35. CrossRef Medline

Rodríguez JJ, Davies HA, Silva AT, De Souza IE, Peddie CJ, Colyer FM, Lancashire CL, Fine A, Errington ML, Bliss TV, Stewart MG (2005) Long-term potentiation in the rat dentate gyrus is associated with enhanced Arc/Arg3.1 protein expression in spines, dendrites and glia. Eur J Neurosci 21:2384-2396. CrossRef Medline
Sadri-Vakili G, Kumaresan V, Schmidt HD, Famous KR, Chawla P, Vassoler FM, Overland RP, Xia E, Bass CE, Terwilliger EF, Pierce RC, Cha JH (2010) Cocaine-induced chromatin remodeling increases brain-derived neurotrophic factor transcription in the rat medial prefrontal cortex, which alters the reinforcing efficacy of cocaine. J Neurosci 30:1173511744. CrossRef Medline

Schank JR, Tapocik JD, Barbier E, Damadzic R, Eskay RL, Sun H, Rowe KE, King CE, Yao M, Flanigan ME, Solomon MG, Karlsson C, Cheng K, Rice KC, Heilig M (2013) Tacr1 gene variation and neurokinin 1 receptor expression is associated with antagonist efficacy in genetically selected alcohol-preferring rats. Biol Psychiatry 73:774-781. CrossRef Medline

Silahtaroglu AN, Nolting D, Dyrskjøt L, Berezikov E, Møller M, Tommerup N, Kauppinen S (2007) Detection of microRNAs in frozen tissue sections by fluorescence in situ hybridization using locked nucleic acid probes and tyramide signal amplification. Nat Protoc 2:2520-2528. CrossRef Medline

Sommer WH, Rimondini R, Hansson AC, Hipskind PA, Gehlert DR, Barr CS, Heilig MA (2008) Upregulation of voluntary alcohol intake, behavioral sensitivity to stress, and amygdala crhrl expression following a history of dependence. Biol Psychiatry 63:139-145. CrossRef Medline

Soulé J, Messaoudi E, Bramham CR (2006) Brain-derived neurotrophic factor and control of synaptic consolidation in the adult brain. Biochem Soc Trans 34:600-604. CrossRef Medline

Tapocik JD, Solomon M, Flanigan M, Meinhardt M, Barbier E, Schank JR, Schwandt M, Sommer WH, Heilig M (2013) Coordinated dysregulation of mRNAs and microRNAs in the rat medial prefrontal cortex following a history of alcohol dependence. Pharmacogenomics J 13:286-296. CrossRef Medline

Tu Y, Kroener S, Abernathy K, Lapish C, Seamans J, Chandler LJ, Woodward JJ (2007) Ethanol inhibits persistent activity in prefrontal cortical neurons. J Neurosci 27:4765-4775. CrossRef Medline

Vendruscolo LF, Barbier E, Schlosburg JE, Misra KK, Whitfield TW Jr, Logrip ML, Rivier C, Repunte-Canonigo V, Zorrilla EP, Sanna PP, Heilig M, Koob GF (2012) Corticosteroid-dependent plasticity mediates compulsive alcohol drinking in rats. J Neurosci 32:7563-7571. CrossRef Medline

Williams AH, Valdez G, Moresi V, Qi X, McAnally J, Elliott JL, Bassel-Duby R, Sanes JR, Olson EN (2009) MicroRNA-206 delays ALS progression and promotes regeneration of neuromuscular synapses in mice. Science 326: 1549-1554. CrossRef Medline

Ying SW, Futter M, Rosenblum K, Webber MJ, Hunt SP, Bliss TV, Bramham CR (2002) Brain-derived neurotrophic factor induces longterm potentiation in intact adult hippocampus: requirement for ERK activation coupled to CREB and upregulation of Arc synthesis. J Neurosci 22:1532-1540. Medline 